\title{
O LAÇADOR: ESPECTRO DE SIGNIFICAÇÃO E IDENTIDADE
}

\author{
O LAÇADOR: RANGE OF MEANING AND IDENTITY
}

\author{
Maria Alice Medeiros Dias* \\ Marcos Pereira Diligenti**
}

\section{RESUMO}

O Monumento d'O Laçador foi concebido para simbolizar o gaúcho, figura emblemática do homem do campo, personagem principal da tradição rio-grandense, trabalhador da lida campeira, protagonista na criação de gado no pampa do Rio Grande do Sul. A obra de Antônio Caringi ocupou durante quarenta e oito anos o Largo do Bombeiro, em uma das entradas da cidade de Porto Alegre, no Estado do Rio Grande do Sul (RS). A sua localização foi um dos fatores que contribuíram para que a escultura fosse incorporada à imagem da cidade e ao imaginário do porto-alegrense como ícone da identidade gaúcha e símbolo da receptividade aos que por ali chegavam. Em 2007, em razão de uma obra viária, a escultura foi deslocada para um espaço público especificamente projetado para recebê-la: o Sítio do Laçador, localizado a menos de um quilômetro do lugar original. Este artigo trata dos impactos causados pelo deslocamento dessa importante escultura pública, investigando a gama de fatores objetivos e subjetivos intrínsecos a esse processo, com ênfase na criação, na implantação em logradouro público, na identificação com a cidade e com a população - ocasionada pela transferência de local da imagem na cidade -, na identidade urbana e no papel d'O Laçador na paisagem de Porto Alegre.

Palavras-chave: Monumento d’O Laçador. Escultura pública. Arte pública. Espaço público. Identidade urbana. Significação urbana.

\footnotetext{
* Arquiteta e urbanista pela Universidade Federal do Rio Grande do Sul (UFRGS). Especialista em Ensino e Pesquisa de Arquitetura pelo Centro Universitário Ritter dos Reis (UniRitter). Especialista em Expressão Gráfica e mestre em Educação pela Pontifícia Universidade Católica do Rio Grande do Sul (PUCRS). Doutoranda em Arquitetura pelo Programa de Pesquisa e Pós-Graduação em Arquitetura (PROPAR) da UFRGS. Professora adjunta, pesquisadora e coordenadora do Departamento de Projetos da Faculdade de Arquitetura e Urbanismo da Pontifícia Universidade Católica do Rio Grande do Sul (FAUPUCRS). Líder do Grupo de Pesquisa CNPq em Paisagismo Urbano. Avenida Ipiranga, 6.681, prédio 9, 90610-001, Partenon, Porto Alegre, RS, Brasil. aliced@pucrs.br

** Engenheiro Civil, mestre e doutor em Educação pela Universidade Federal do Rio Grande do Sul (UFRGS). Pós-doutor em Arquitetura e Urbanismo pelo Instituto Superior Técnico (IST) de Lisboa e pela Pontificia Universidad Católica de Chile (UC). Professor titular e pesquisador da Faculdade de Arquitetura e Urbanismo da Pontifícia Universidade Católica do Rio Grande do Sul (FAUPUCRS). Membro do Núcleo de Habitação de Interesse Social e Sustentabilidade da FAUPUCRS. Coordenador do Grupo de Pesquisa SUSTENFAU (Sustentabilidade Social e Avaliação Pós-ocupacional). Associado ao Instituto Brasileiro de Direito Urbanístico (IBDU). Membro do International Federation for Housing and Planning (IFHP). Líder do Grupo de Pesquisa em Habitação de Interesse Social e Sustentabilidade do Conselho Nacional de Desenvolvimento Científico e Tecnológico (CNPq). Avenida Ipiranga, 6.681, prédio 9, 90610-001, Partenon, Porto Alegre, RS, Brasil.

mdilig@pucrs.br
} 


\begin{abstract}
O Laçador was designed to symbolize the gaucho, the strength of the emblematic figure of the peasant, the main character of Rio Grande tradition, countryside worker and protagonist of livestock in Rio Grande do Sul pampa. The work of artist Antônio Caringi has been located for forty-eight years in Largo do Bombeiro, at one of the entrances of Porto Alegre (RS), a place that, for its location, contributed to the sculpture's incorporation into the city's image and thus to the imaginary of Porto Alegre's citizens as icon of the city's identity and as a symbol of receptivity to those who arrived there. In 2007, due to a road project covering the original site, the sculpture was moved to a public open space specially designed to receive it: O Sitio do Laçador, less than a kilometer from the original place. The article discusses the route of this important public sculpture: creation, deployment in public area, identification with the city and the population, local transfer and impact of this change onto the city's image, in the urban identity and in the role of $\mathrm{O}$ Laçador in Porto Alegre's landscape.
\end{abstract}

Keywords: O Laçador monument. Urban sculpture. Public art. Urban identity. Urban signification.

\title{
INTRODUÇÃO
}

O olhar no infinito, na saída da porteira, olhando o gado para laçá-lo. É o domínio sobre o animal, não é somente controlá-lo. Eu tenho uma missão. Eu sou $O$ Laçador. (PAIXÃO CÔRTES, 2012 apud MAGS, 2012).

O monumento d'O Laçador, de Antônio Caringi', localizado na confluência das avenidas Farrapos, Ceará e dos Estados com a BR-116, caracterizou a entrada de Porto Alegre pela zona norte ao longo de quase cinco décadas, a partir de sua inauguração, em 20 de setembro de 1958, no lugar então denominado Largo do Bombeiro. A escultura, em seu local original, converteu-se em elemento marcante da imagem da cidade e referência urbana, tanto por sua potência plástica quanto por sua evocação simbólica. Em 31 de março de 2007, quando foi relocada para o Sítio do Laçador, a cerca de 600 metros do lugar de origem, consolidou-se uma intervenção que impactou a paisagem urbana porto-alegrense. No sítio original, construiu-se um viaduto. No novo sítio, $O$ Laçador deixou de ser uma referência urbana para tornar-se um monumento de visitação, um ponto turístico em um lugar delimitado por duas vias paralelas: a estrada BR-116 e a avenida dos Estados (figura 1).

\section{A IDENTIFICAÇÃO DOS RIO-GRANDENSES COM O GAÚCHO}

Originário do espanhol platino, o termo gaúcho inicialmente designava um indivíduo marginal, contrabandista, ladrão de campo ou vagabundo. (FLORES, 2012). A representação do gaúcho no imaginário popular, como a personificação do herói, do trabalhador, estereotipada, foi construída ao longo da história do Estado do Rio Grande do Sul, cultivada na música e na literatura regionalistas e pelos grupos tradicionalistas.

Escultor pelotense que viveu de 1905 a 1981 . Foi um dos artistas mais premiados e o maior estatuário da História da Arte do Rio Grande do Sul. Entre suas principais obras destacam-se: o monumento do Expedicionário, no parque Farroupilha, e a estátua Equestre de Bento Gonçalves, ambos em Porto Alegre; o monumento do Imigrante, em Caxias do Sul; o monumento do Sentinela Farroupilha, em Pelotas. (PAIXÃO, 1988; MÜTZENBERG, 2006). 


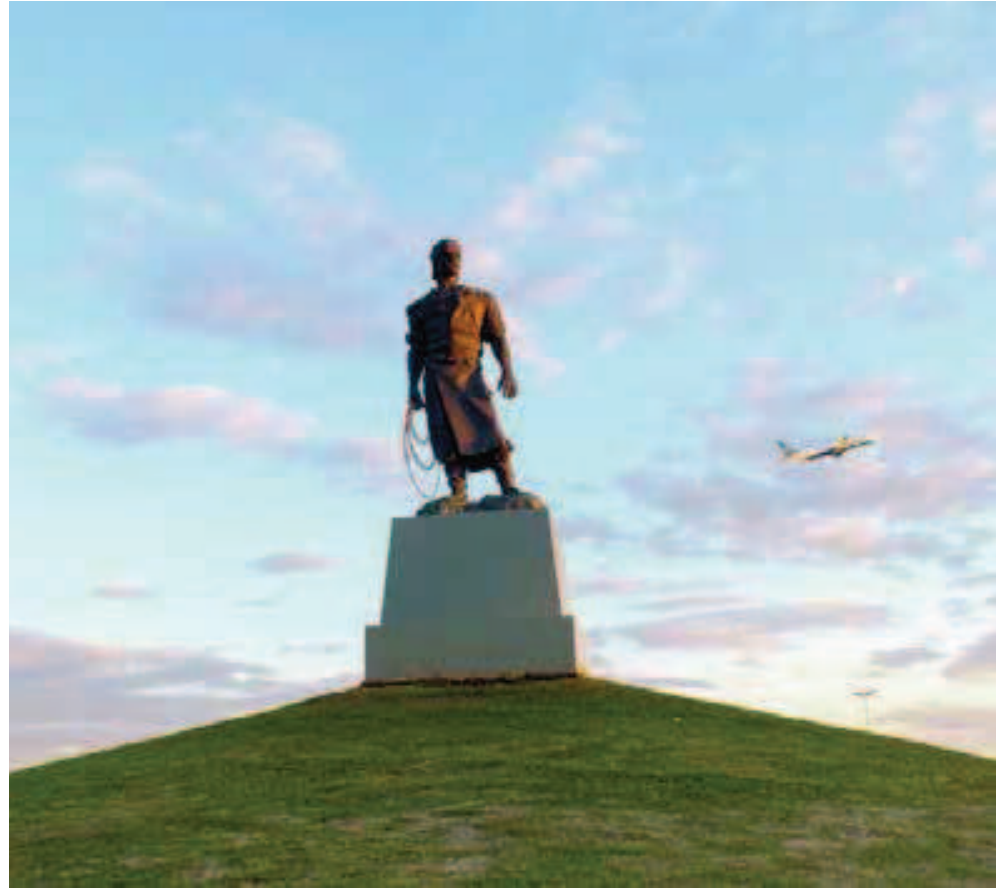

Figura 1

Monumento d'O Laçador. Fonte: Acervo dos autores 31 mai. 2015.

No Rio Grande do Sul, forjou-se o "Mito do Gaúcho" [...] Este mito faz parte das manifestações do Imaginário sul-rio-grandense, alimentado pelo culto exacerbado às Tradições heroicas de uma História que continuamente "canta seus heróis em prosa e verso", como uma necessidade atávica de afirmação e inculcação de um passado de glórias, criando-se o "orgulho de ser gaúcho", mantendo assim uma identidade regional, resultante de uma construção social apaziguadora das grandes diferenças sociais existentes nos campos e nas cidades. (GUEDES, 2009, p. 53).

A identificação dos rio-grandenses-do-sul com o "Mito do Gaúcho", com o passar do tempo, resultou na significação do termo como o gentílico dos nascidos no Estado sulino. A indumentária do gaúcho é um aspecto de destaque na caracterização desse personagem mítico. Sua vestimenta, adequada à performance do ginete e à lida no campo, apresenta peças típicas, como a camisa de mangas largas, a bombacha, o chiripá, o cinto largo, as botas de couro, o tirador, o lenço e o chapéu. A composição dessa indumentária apresenta variações nas diversas expressões do arquétipo gauchesco.

\section{O GAÚCHO NA ESTATUÁRIA DE PORTO ALEGRE}

A presença do gaúcho na arte escultórica pública da capital está representada, desde as primeiras décadas do século XX, por meio de duas obras localizadas em dois dos principais logradouros públicos da cidade: a praça da Matriz (praça Marechal Deodoro) e o parque Farroupilha.

Segundo Alves (2004), o primeiro gaúcho retratado na estatuária do Rio Grande do Sul foi o que compõe o monumento a Júlio de Castilhos. A obra, de autoria do 
artista Décio Villares², inaugurada em 25 de janeiro de 1913 na praça Marechal Deodoro, apresenta em sua face posterior a estátua equestre de um gaúcho (figura 2). 0 monumento foi concebido para sintetizar a importância cívica e política de Júlio Prates de Castilhos, o primeiro governante republicano do Rio Grande do Sul.

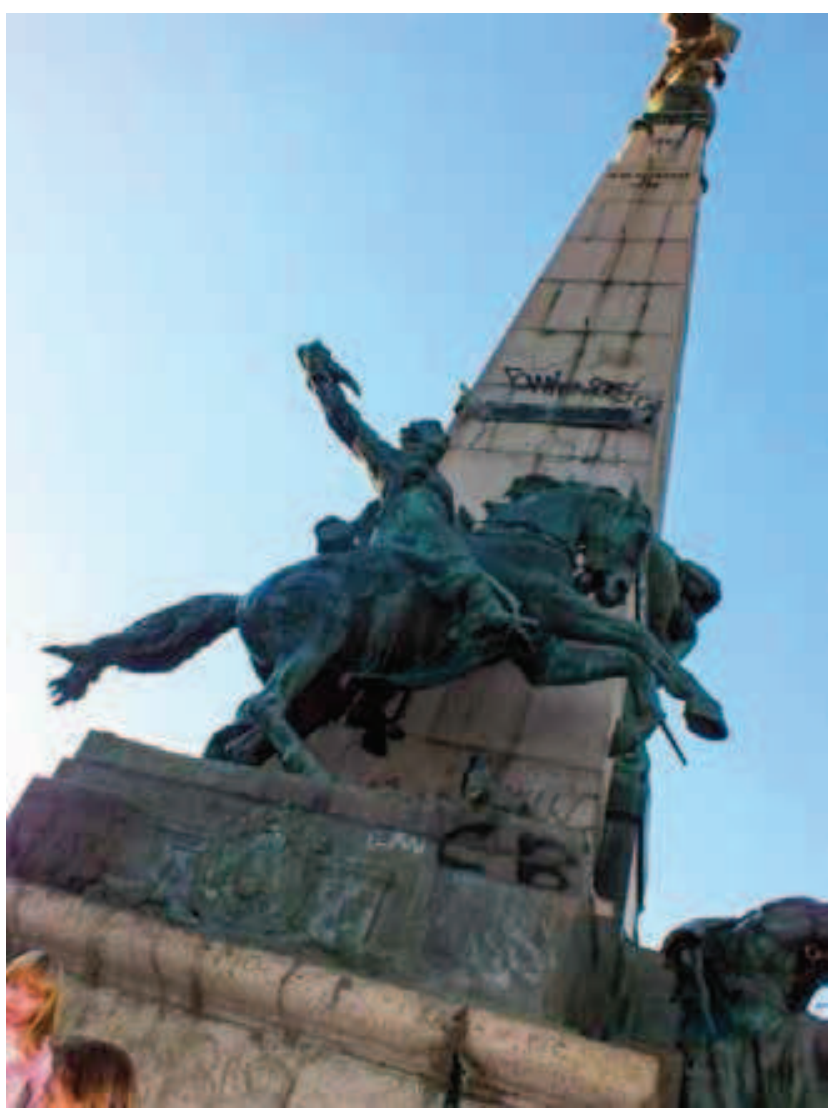

Figura 2 Monumento a

Júlio de Castilhos.

Fonte: Acervo dos autores -

31 mai. 2015.

A segunda intervenção estatuária focada na representação do gaúcho no Estado deu-se com a obra O Gaúcho Oriental, de Federico Escalada ${ }^{3}$, estátua pedestre fundida em bronze e instalada em 1935, no parque Paulo Gama, recanto situado na extremidade norte do parque Farroupilha, entre a avenida João Pessoa e a rua Luiz Englert. A escultura (figura 3), em tamanho natural, do gaúcho em "pose descontraída" e vestindo um chiripá, foi presenteada ao Estado pela comunidade uruguaia domiciliada em Porto Alegre, como homenagem ao centenário da Revolução Farroupilha ${ }^{4}$. (ALVES, 2004; AXT; SCLIAR, 2011). Em que pese ao valor artístico e a relevância dessas esculturas, a

2 Pintor, escultor e desenhista carioca que viveu entre 1851 e 1931.

3 O escultor uruguaio Federico Augusto Escalada Pons (1888-1960) é autor de diversas obras que registram as atividades do gaúcho, o homem do campo característico do meio rural do Uruguai, da Argentina e do Rio Grande do Sul. Fonte: Fundación MonROU, 1992.

4 A Revolução Farroupilha, ou Guerra dos Farrapos, foi regional, de caráter republicano, contra o Governo Imperial do Brasil, na então Província de São Pedro do Rio Grande do Sul. O movimento resultou na declaração de independência da província como Estado republicano, dando origem à República Rio-Grandense. Estendeu-se de 20 de setembro de 1835 a $1^{\circ}$ de março de 1845. 
força do gaúcho como síntese dos ideais de um povo teve a sua expressão escultórica mais potente em $\bigcirc$ Laçador, de Antônio Caringi.

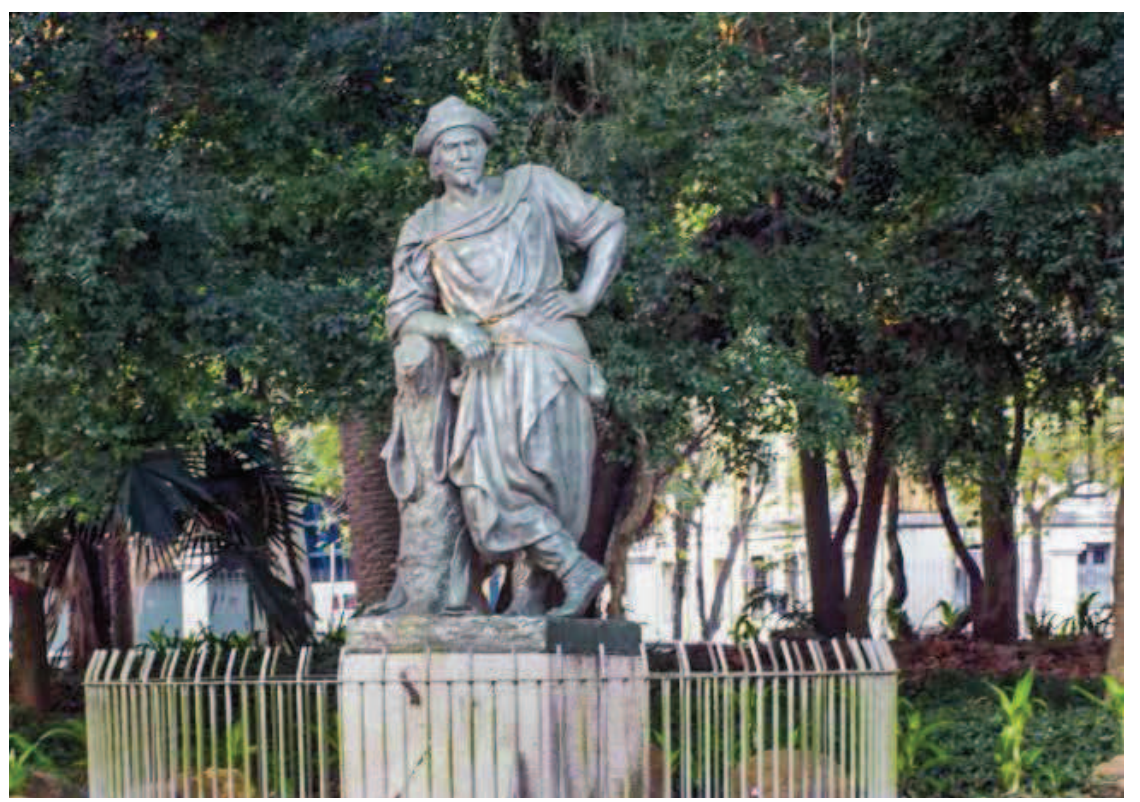

Figura 3 Gaúcho Oriental - Parque Farroupilha. Fonte: Acervo dos autores - 31 mai. 2015.

Caringi viveu na Europa de 1928 a 1940 e realizou estudos em Munique e Berlim, onde recebeu influência da escultura neoclássica e germano-grega. Sua produção escultórica era figurativa, e a figura humana foi o tema principal de sua obra. Seu conjunto de trabalhos de cunho regionalista ${ }^{5}$ destaca-se como aspecto de sua personalidade artística. O Laçador é sua obra mais conhecida, considerado o ápice de sua produção artística. Obra que encarnou o gaúcho e se integrou de maneira profunda ao significado da figura mítica, expressão máxima da identidade e da cultura rio-grandenses. (PAIXÃO, 1988; MÜTZENBERG, 2006).

\section{O GAÚCHO DE CARINGI: O LAÇADOR}

Agora ele não procura apenas um ideal de beleza. Embora esse exista na obra, o artista representa, na mesma, o que sente, embasado no que vê. Ela transmite a mensagem do Rio Grande do Sul [...] e a figura do gaúcho se insere na paisagem não como contraste, mas integrando-se a ela. (PAIXÃO, 1988, p. 93).

O Laçador foi exibido pela primeira vez no dia 20 de agosto de 1954, no estande do Rio Grande do Sul na Exposição-Feira Internacional do Parque do Ibirapuera, evento

O Laçador, O Gaúcho Montado, O Posteiro, O Negrinho do Pastoreio, O Farrapo, O Índio Charrua e O Sentinela Farroupilha são algumas das obras em que Caringi explora conteúdos regionais. (PAIXÃO, 1988; MÜTZENBERG, 2006). 
comemorativo do quarto centenário da cidade de São Paulo. A escultura, executada em gesso, seria doada para a capital paulista. A obra foi escolhida por meio de concurso público, do qual participaram Caringi e os renomados artistas Vasco Prado e Fernando Corona. Inicialmente executada em gesso, a escultura foi adquirida pela Prefeitura Municipal de Porto Alegre, na gestão do então prefeito Leonel de Moura Brizola, sendo fundida em bronze para posterior instalação em logradouro público. (ALVES, 2004; FLORES, 2012). No dia 20 de setembro de 1958, a obra em bronze que mostrava um gaúcho tipicamente pilchado 6 , com 4,45 metros de altura e 3,8 toneladas, instalada em pedestal de concreto de cerca de 2,20 metros de altura, foi oficialmente inaugurada pelo vice-prefeito, Sucupira Vianna, no Largo do Bombeiro. (FLORES, 2012).

As feições e o corpo d'O Laçador expressam a idealização das características físicas do habitante dos pampas gaúchos. Postura elegante, ereta, pernas levemente afastadas, misto de serenidade e seriedade no semblante conferem ao personagem expressão corporal e facial compatíveis com a representação de uma personalidade reta, altiva, sobranceira, de firmes propósitos e caráter heroico.

Sobre a composição da figura escultórica, Paixão (1988, p. 93) observa:

De beleza singular, apresenta-se com a cabeça descoberta, tendo a vincha a circundá-la; os cabelos de bugre são lisos e atirados para trás. O rosto possui expressão enérgica e é característica principal a dignidade das feições. O lenço está disposto esteticamente sobre os ombros, caindo mais sobre um lado. A camisa é simples, de mangas arregaçadas, acima do cotovelo. Na cintura, se prende o tirador.

O Laçador é a realização máxima de Antônio Caringi. Na concepção da obra, o artista inspirou-se na figura do tradicionalista João Carlos D'Ávila Paixão Côrtes, que vestiu sua indumentária gauchesca para ser a referência viva do escultor (figuras 4 e 5).

As características da escultura foram propositalmente adotadas como forma de marcar o estereótipo campeiro, ou ainda, segundo Alves (2004, p. 112):

[...] o que realmente destaca o Laçador das demais representações do gaúcho é que ele é uma figura feita com o objetivo de ser símbolo [...] com representação idealizada, estereotipada - muito adequada para um símbolo mítico, além de ser estrategicamente localizada (por enquanto) ${ }^{7}$. Certamente, esses foram os motivos pelos quais os tradicionalistas, e posteriormente a vida da cidade, resolveram escolher o Laçador como símbolo, não só de Porto Alegre, mas, por extensão, da terra dos gaúchos.

Instalada no Largo do Bombeiro, a presença icônica d'O Laçador consolidou-se ao longo de quase meio século como "cartão-postal" da cidade. Sua posição estratégica, aliada ao forte apelo simbólico e à grande expressividade plástica, definiram seu status

\footnotetext{
6 Vestido com a indumentária gauchesca.

7 O texto citado foi publicado em 2004, portanto, três anos antes do deslocamento do Monumento.
} 
de referência identitária da cidade. Segundo Alves (2004, p. 111): “Está para o estado assim como o Cristo Redentor está para o Rio de Janeiro; as Bandeiras de Brecheret para São Paulo; a estátua da Liberdade para Nova lorque; a Torre Eiffel para Paris."
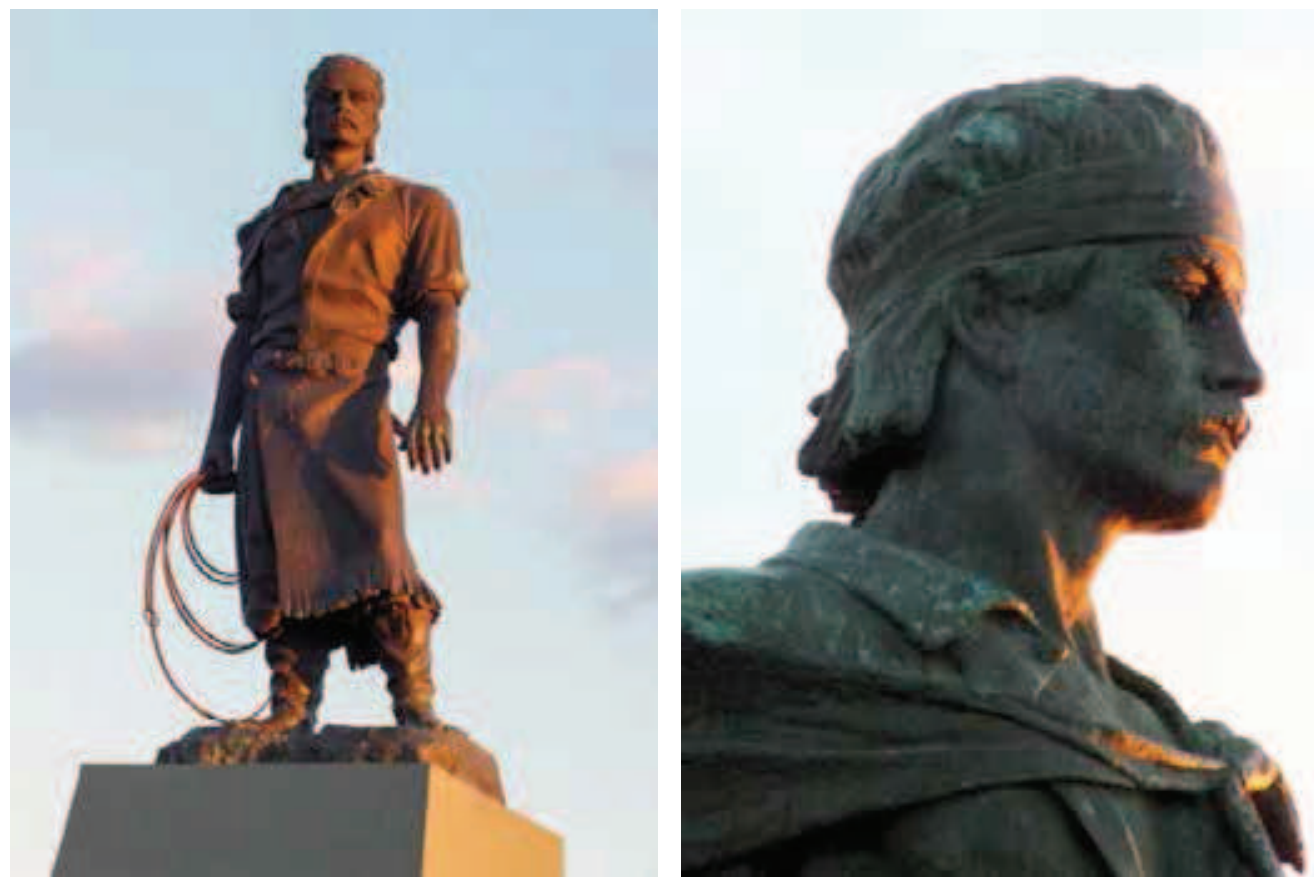

Figuras 4 e 5

O Laçador - o todo e detalhe aproximado.

Fonte: Acervo dos autores - 31 mai. 2015.

Em 1991, uma votação popular a escolheu como símbolo da cidade de Porto Alegre. No certame, recebeu $32,1 \%$ dos votos (175.953 do total de 548.757 votos) e concorreu com os seguintes ícones da cidade (citados por ordem decrescente de votação): Pôr-do-sol do Guaíba; rio Guaíba; Casa de Cultura Mário Quintana; parque Farroupilha; rua da Praia; Usina do Gasômetro; Ponte de Pedra; Catedral; parque Marinha do Brasil; teatro São Pedro; Chalé da Praça XV; parque Moinhos de Vento; praça da Matriz e praça da Alfândega. (FLORES, 2012). Em 1992, por intemédio da Lei Complementar n 279/92, o "Monumento do Laçador" foi instituído como símbolo oficial da cidade de Porto Alegre. Pode-se observar, nas figuras 6 e 7, a importância histórica do monumento retratado em cartões-postais da década de 1960.

A escultura foi tombada de acordo com a Lei Complementar $n^{\circ} 275 / 92$, que dispõe sobre a proteção do Patrimônio Histórico, Cultural e Natural do Município de Porto Alegre, disciplina a integração de bens móveis e imóveis, cria incentivos ao tombamento e dá outras providências. Segundo a referida lei:

Constitui o Patrimônio Histórico-Cultural, Natural e Paisagístico do Município e o conjunto de bens móveis e imóveis e os espaços existentes em seu território e que, 
por sua vinculação a fatos pretéritos memoráveis, a fatos atuais significativos por seu valor cultural ou natural, ou por sua expressão paisagística, seja de interesse público preservar e proteger contra ações destruidoras. (PORTO ALEGRE, 1992).
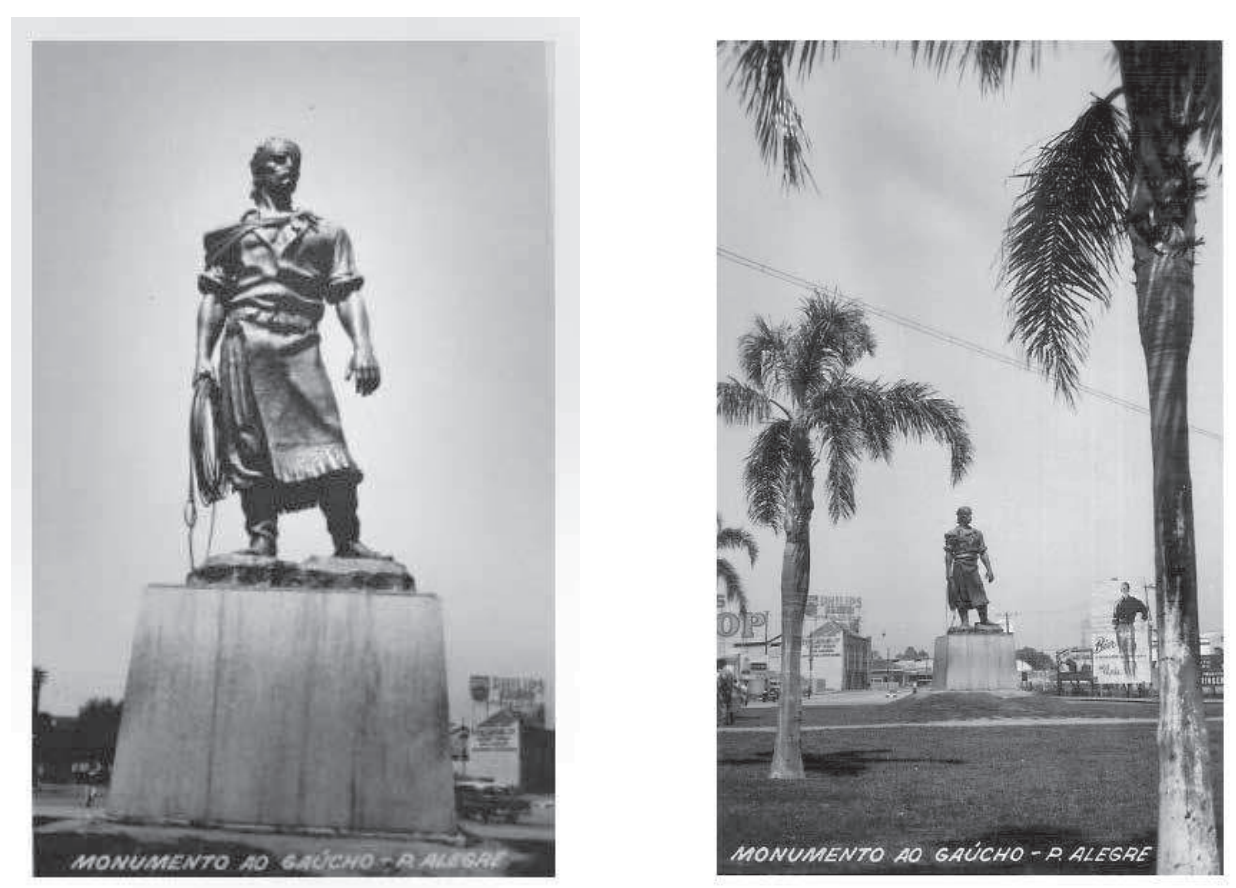

Figuras 6 e 7 Cartões-postais Canazaro - década de 1960.

Fonte: Disponível em: www.mercadolivre.com.br - Acesso em: 30 mai. 2015.

Conforme análise e parecer do Conselho Municipal do Patrimônio Histórico e Cultural (Compahc), em 17 de setembro de 2001, o Monumento do Laçador foi inscrito no Livro Tombo n 62 (página 2, vol. 2, Processo 1.016791.00.2) e passou a integrar - Patrimônio Cultural de Porto Alegre.

Em 15 de maio de 2008, o Diário Oficial da Assembleia Legislativa do Estado do Rio Grande do Sul publicou pareceres da Comissão de Constituição e Justiça e da Comissão de Educação, Cultura, Desporto, Ciência e Tecnologia, favoráveis ao Projeto de Lei n⿳ 13/2006, por meio do qual a Estátua do Laçador foi declarada integrante do Patrimônio Histórico e Cultural e escultura símbolo do Estado do Rio Grande do Sul. (RIO GRANDE DO SUL, 2008).

\section{O DESLOCAMENTO d'O LAÇADOR}

Embora tombado pela Prefeitura Municipal em 2001, o monumento não teve assegurada a sua permanência no local original. Paradoxalmente, o parecer do tombamento, ao invés de garantir a preservação da obra e a proteção do seu entorno, respaldou sua transferência, que ocorreria seis anos depois. (ALVES, 2004).

A transferência da localização do monumento foi definida no âmbito do projeto de implantação do viaduto Leonel Brizola. A construção deste, com cerca de 700 metros 
de comprimento, dividido em duas alças de 6,4 metros de comprimento - que cruzam a avenida Farrapos e a linha do metrô -, fez parte da implantação do Programa Integrado Entrada da Cidade (PIEC) e teve como objetivo a facilitação do acesso aos bairros Humaitá, Navegantes e Anchieta por meio da ligação da Terceira Perimetral à BR-290 (detalhe na figura 8).

A transferência do monumento realizou-se com o auxílio da instalação de cintas de poliéster afixadas na estrutura de sustentação, espécie de gaiola de aço, içando-o por guindaste e transportando por caminhão até o novo espaço destinado a recebê-lo. (PORTO ALEGRE, 2007). O deslocamento está ilustrado na figura 9.

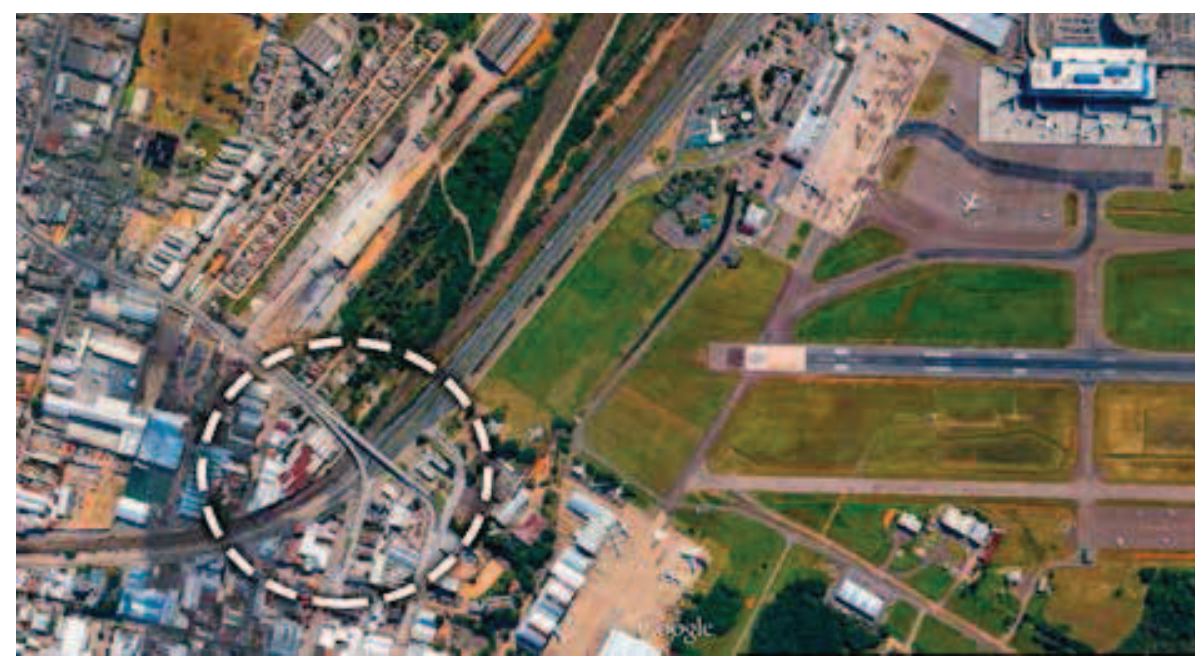

Figura 8 Viaduto Leonel Brizola.

Fonte: Disponível em: <https://www.google.com/earth/>, 2015. Imagem acessada e processada pelos autores em dez. 2015.

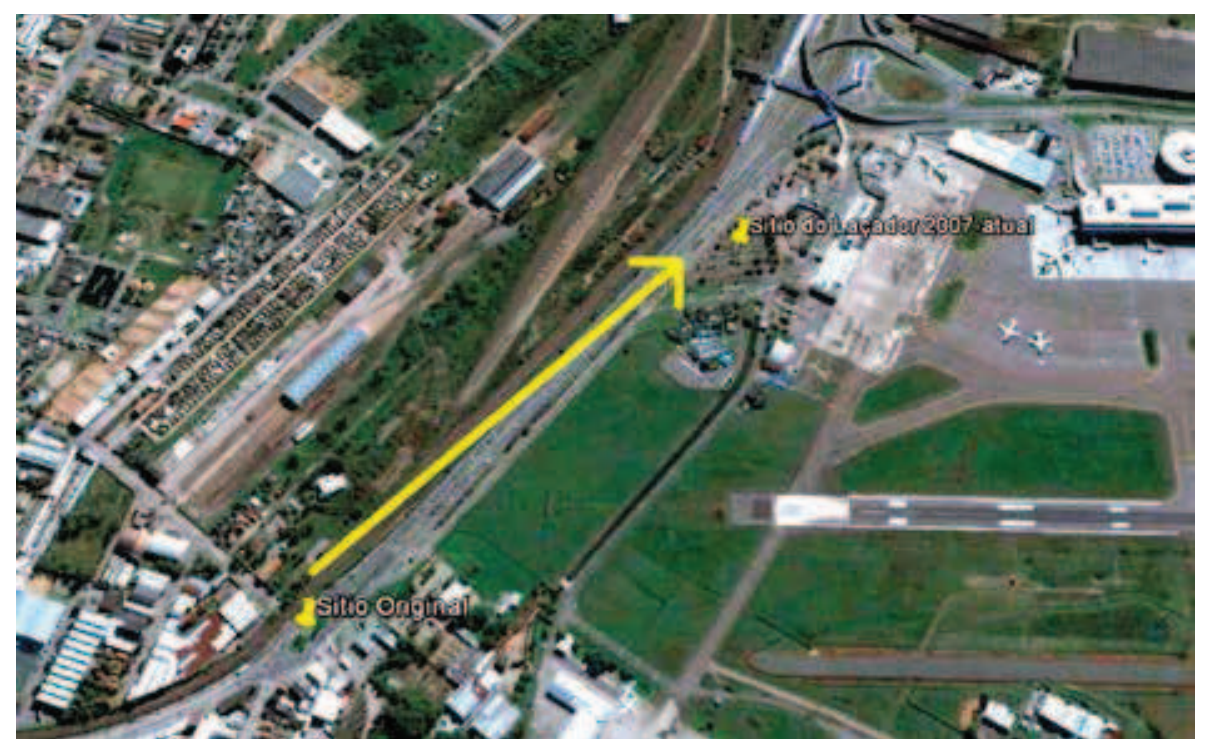

Figura 9 Deslocamento d'O Laçador.

Fonte: Disponível em: <https://www.google.com/earth/>, 2002. Imagem acessada e processada pelos autores em dez. 2015. 


\section{O SÍTIO DO LAÇADOR}

A obra do espaço denominado Sítio do Laçador, logradouro público de cerca de 4 mil m², localizado na avenida dos Estados, nas imediações do Terminal 2 do aeroporto Salgado Filho, foi executada por técnicos das Secretarias Municipais de Gestão e Acompanhamento Estratégico (SMGAE), Obras e Viação (SMOV) e do Meio Ambiente (SMAM). O projeto paisagístico foi desenvolvido pelo arquiteto Sérgio Mantovani, integrante do quadro técnico da SMAM da Prefeitura de Porto Alegre. A escolha de um local próximo ao lugar original da escultura demonstra a preocupação presente no projeto no sentido de evitar mudança geográfica radical na localização da mesma. Segundo a prefeitura municipal, a obra contou com a aprovação de lideranças do Movimento Tradicionalista Gaúcho. (PORTO ALEGRE, 2007). Na figura 10, observa-se a vista aérea do novo sítio.

A escolha de um local próximo ao lugar original da escultura demonstra a preocupação presente no projeto no sentido de evitar mudança geográfica radical na localização da mesma. Segundo a prefeitura municipal, a obra contou com a aprovação de lideranças do Movimento Tradicionalista Gaúcho. (PORTO ALEGRE, 2007). Na figura 10, observa-se a vista aérea do novo sítio.

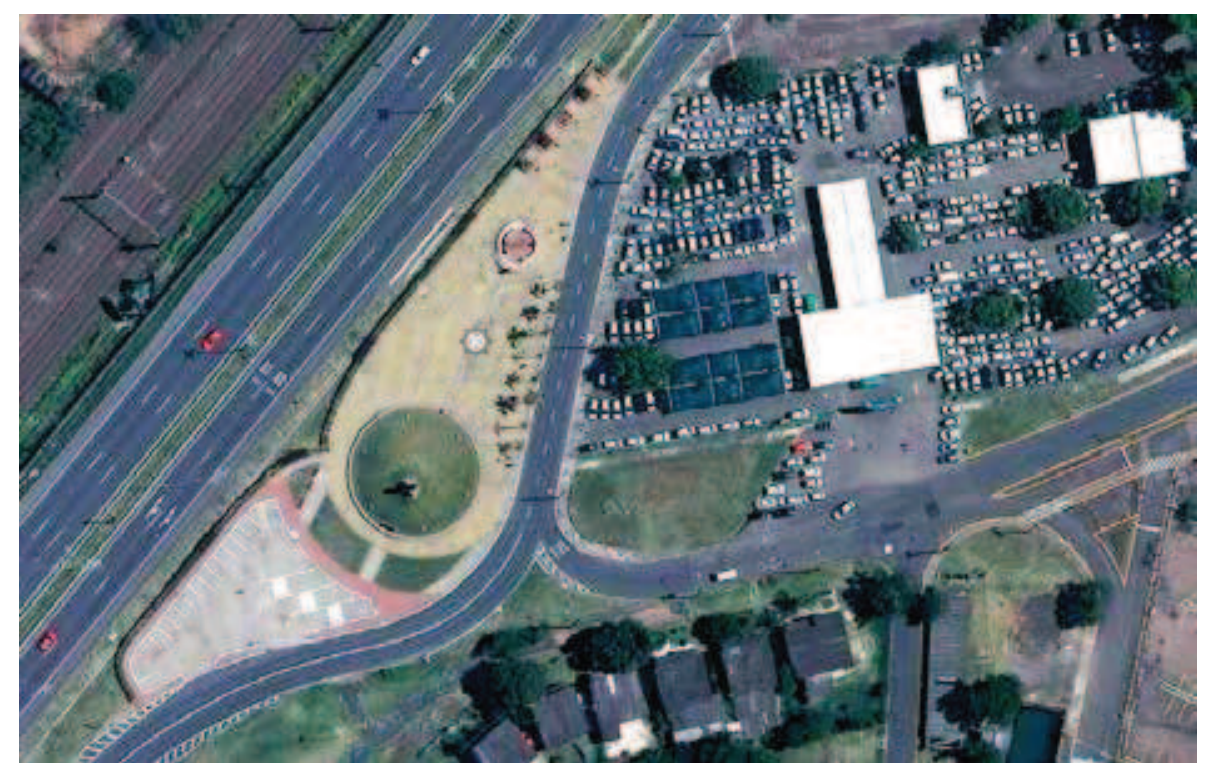

Figura 10 Vista aérea do Sítio do Laçador.

Fonte: Disponível em: <https://www.google.com/earth/>. Acesso em: 30 mai. 2015.

O sítio apresenta características de ponto turístico e lugar de visitação, concebido para receber pessoas que acessam o local em veículos particulares ou ônibus fretados. O espaço organiza-se em uma sequência de seis ambientes: 1) o estacionamento para quinze automóveis de passeio e três ônibus; 2) o Anel Verde, que liga o estacionamento ao espaço principal, cortado por caminhos pavimentados; 2) a Coxilha do Laçador, ambiente principal, formada por talude de volume cônico com 3,5 metros de altura, 
onde está implantado o pedestal e a escultura $O$ Laçador; 3) o Largo dos Gaúchos, espaço pavimentado, com o desenho de uma Roda dos Ventos no centro e um renque de oito palmeiras nativas (jerivás) ${ }^{8}$ em uma das bordas (com área de $1.000 \mathrm{~m}^{2}$, o Largo destina-se a atividades de lazer e eventos comunitários); 4) a Plataforma Cívica, com $70 \mathrm{~m}^{2}$, equipada com pira para acendimento da Chama Crioula do Movimento Tradicionalista, mastros para hasteamento de bandeiras e placa com a letra do Hino Rio-grandense; 5) o Recanto da Tradição, conjunto de estares com bancos e canteiros vegetados com herbáceas e mudas de erva-mate, a árvore símbolo do Rio Grande do Sul. Pode-se observar, nas figuras 11 e 12, o monumento com os equipamentos anexados ao sítio de visitação.

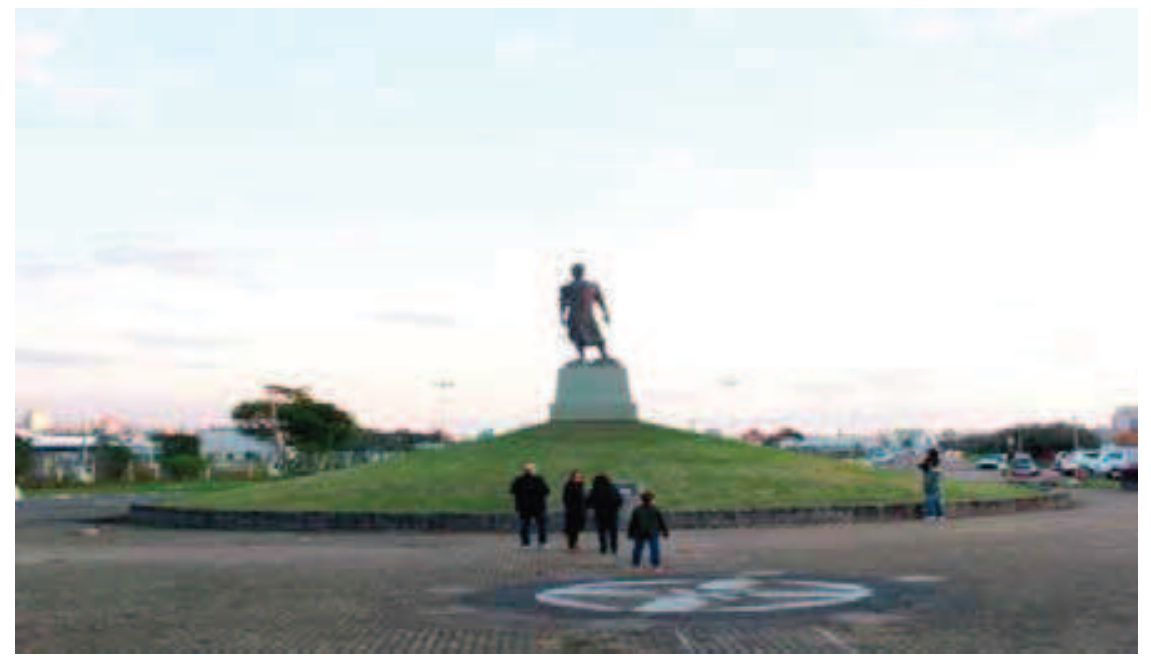

Figura 11

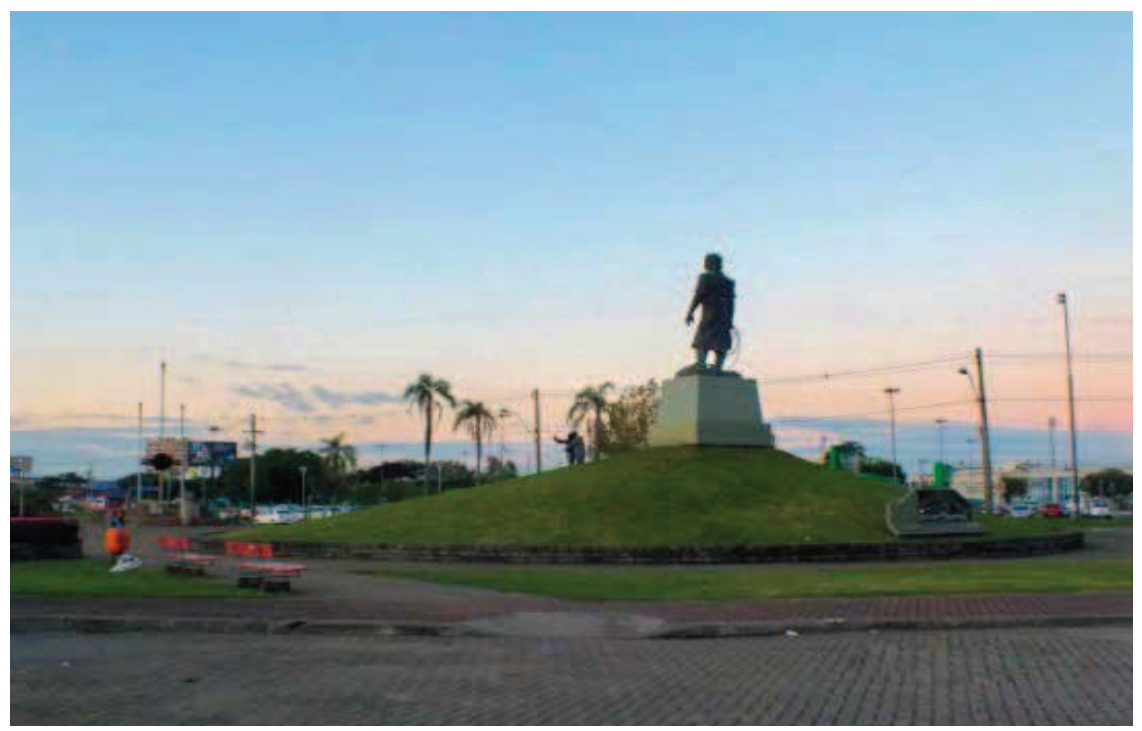

Figura 12

Figuras 11 e 12 Visual do Largo dos Gaúchos e do estacionamento. Fonte: Acervo dos autores - 31 mai. 2015.

8 As oito palmeiras (jerivás) homenageiam o Grupo dos Oito, que, liderados por Paixão Côrtes, realizaram em 1947 a cavalgada que marcou o nascimento do atual Movimento Tradicionalista Gaúcho. 
Oito anos após a inauguração, o Sítio do Laçador apresenta problemas de conservação (figura 13). Em 2012, o tradicionalista Paixão Côrtes (que, conforme citado, serviu de modelo para a execução do monumento) manifestou inconformidade em relação a alguns aspectos observados no novo sítio, inclusive quanto às condições da própria escultura, cujo laço estaria descaracterizado e fora das proporções corretas. (MAGS, 2012).

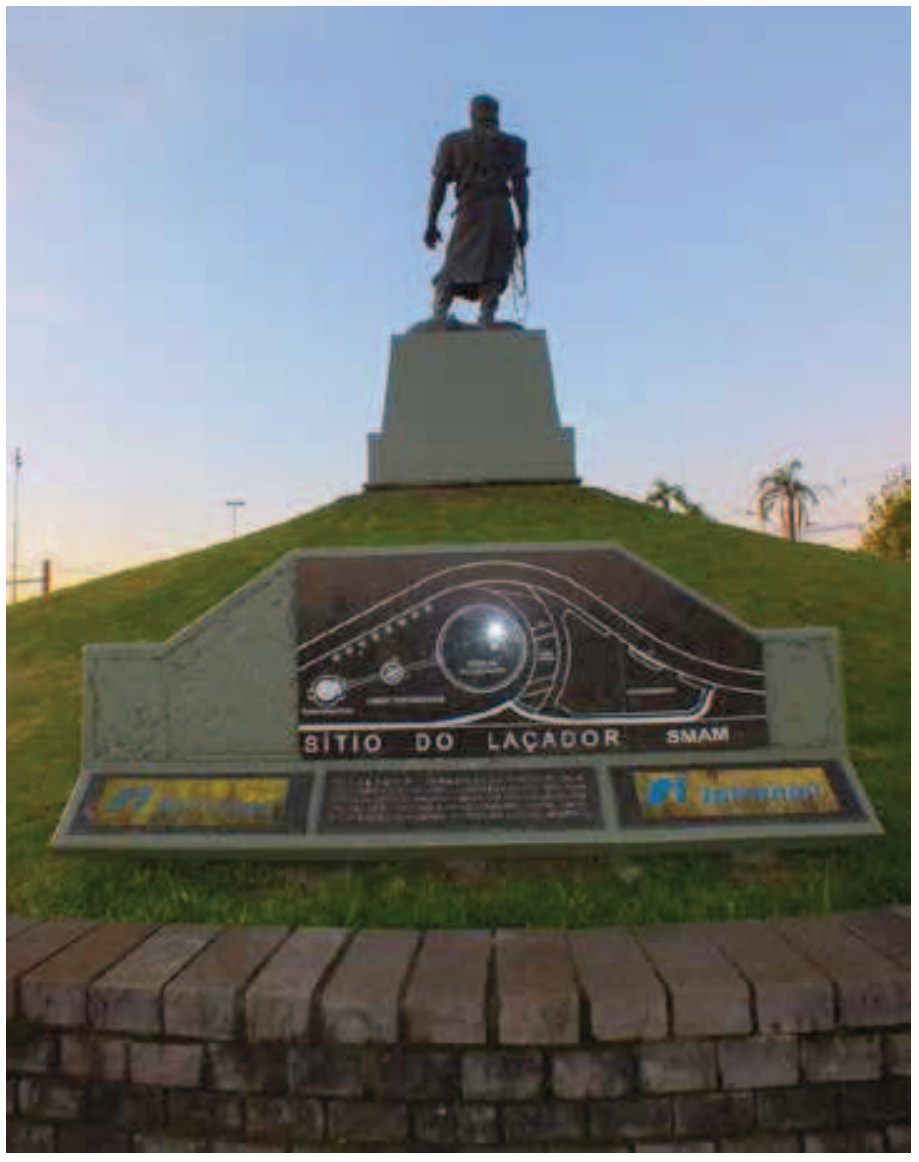

Figura 13 Placa com o

mapa do sítio em estado de degradação.

Fonte: Acervo dos autores 31 mai. 2015.

Verificamos que o Sítio do Laçador apresenta, em 2015, condições de precariedade em sua manutenção pelo poder público.

\section{O LAÇADOR: SIGNIFICADO E IDENTIDADE URBANOS}

Uma dada situação não pode ser plenamente apreendida se, a pretexto de contemplarmos sua objetividade, deixamos de considerar as relações intersubjetivas que a caracterizam. (SANTOS, 2006, p. 214).

Com base nos fundamentados da conceituação de Augé (1994), destaca-se a relevante diferenciação entre espaço e lugar. Segundo o autor, o lugar transcende a ideia de espaço à medida que é incorporado à vitalidade urbana, que passa a fazer parte da vida cotidiana, objetiva ou subjetiva dos cidadãos. Direcionando a análise de 
forma mais centrada nos monumentos públicos, Alves diz:

O fato mais relevante sobre $O$ Laçador é que embora essa escultura-símbolo não tenha sido idealizada e projetada para o local, ela subverteu a lógica do site-specific ${ }^{9}$ ao dar espírito para aquele espaço, até então sem qualquer referência ou significado. O lugar hoje só tem razão de ser por causa da obra. É um símbolo ligado ao lugar. Durante os 45 anos em que ali se encontra a escultura elaborou no imaginário dos cidadãos o espírito do lugar - daquele local. (ALVES, 2004, p. 67).

Comentando a importância de sua localização original - que perdurou até o ano de 2007 - na constituição identitária da obra, o autor reforça:

Resumindo sobre esta importante obra: o Laçador enquanto símbolo de Porto Alegre instituído pela vida da cidade é uma construção simbólica tanto do ponto de vista iconográfico quanto a respeito de sua localização. A estátua é indissociável daquele lugar que ela firmou na memória coletiva da cidade. Ali houve uma subversão da questão da especificidade do local, a posteriori da instalação da obra. Desse modo, aquele espaço não será mais o mesmo se a estátua for retirada daquele lugar, que provavelmente será transformado por um viaduto. Quando um carro de bombeiros vindo do aeroporto chegar com atletas vitoriosos e passar por ali, sem a estátua, a impressão será de que se estará em outra cidade. Haverá uma presença do símbolo somente no imaginário das pessoas. (ALVES, 2004, p. 69).

Como é possível inferir, a instalação de um monumento urbano transcende, em muito, possíveis análises simplificadoras e aponta nuances de grande complexidade na vida da cidade e de seus cidadãos. Restringir essa percepção seria incorrer em um viés indiscutivelmente reducionista. Concordamos com Dias $(2012$, p. 9) e sua proposta de percepção da cidade "[...] não como um local de transitoriedades constantes e movimento desordenado, mas como local onde o cidadão deve se reconhecer e identificar frente aos objetos e demais produtos da ação cultural humana".

Ainda procurando esclarecer os significados de imagem pública como marco urbano em relação à sua forma, encontramos em Lynch (2010) uma importante classificação. Para ele, os elementos da imagem urbana podem ser categorizados em cinco tipos: vias, limites, bairros, cruzamentos e elementos marcantes. Nessa perspectiva, o objeto de estudo aqui proposto - o Monumento d'O Laçador - contempla simultânea e complementarmente duas categorias: a de elemento (ou ponto) marcante e a de cruzamentos. Essa interface se dá na medida em que o Monumento preenche a condição de elemento marcante por caracterizar-se em um objeto escultural físico que se encontra na forma de exterioridade, porém não prescindindo dos aspectos complementares de identidade

9 O termo site-specific é usado quando a obra é pensada e realizada para ocupar um espaço determinado e concreto. Assim a obra só tem significado no lugar onde foi concebida, aproveitando as condições físicas, ambientais, sociais ou históricas do lugar e relacionando-se com suas dimensões, materiais, texturas e cores, captando um determinado carácter emotivo próprio ou alguma propriedade física do espaço ou de seus habitantes. (NOVAIS, 2010). 
com a população. Por outro lado, o monumento também se enquadra na forma de cruzamento, por ter sido inserido, em sua posição original, no centro de uma rótula de trânsito intenso que configurava determinantemente, objetiva e subjetivamente, o limite de entrada/saída da cidade. Essa dualidade classificatória justifica-se na medida em que a cidade e seus elementos constitutivos se relacionam de forma interdependente, temporal e constante, de acordo com a sua evolução urbana.

Enquanto organismo vivo e pulsante, a cidade tem sua imagem transformada continuamente. As paisagens urbanas modificam-se, através do tempo, em vários graus e dimensões - por meio de intervenções que, na maioria das vezes, destinam-se ao incremento dos usos do solo urbano e a soluções de problemas de mobilidade urbana. No entanto, essas transformações deveriam respeitar a permanência das características/ elementos que se firmaram no imaginário da população como portadores de significado cultural e representantes da identidade urbana.

Cullen (2009) destaca a comunicação com o público como o objetivo fundamental das intervenções urbanas. Nesse sentido, fica realçada a demanda dirigida aos urbanistas concernente à identificação dos sinais físicos que pontuam as perspectivas dos locais da cidade e estabelecem ligação emocional com o cidadão. Segundo o autor: "[...] se compararmos uma perspectiva a uma frase gramatical com sujeito e predicado, podemos utilizar o termo pontuação para designar determinadas formas de demarcação do espaço no seio dessa frase". (CULLEN, 2009, p. 47). A supressão de elementos de demarcação urbana que definem um dado local constitui-se em uma intervenção destrutiva do lugar, legando à cidade uma frase que, sem pontuação, tem seu entendimento prejudicado.

O lugar original de $\bigcirc$ Laçador estabelecia sua condição como elemento distintivo e orientador, constituinte da imagem mental dos habitantes e visitantes da capital gaúcha. Segundo Lynch (2010, p. 4), a imagem ambiental que concorre para a legibilidade da cidade "[...] é produto tanto da sensação imediata quanto da lembrança de experiências passadas". O autor define imaginabilidade como:

[...] a característica, num objeto físico, que lhe confere uma alta probabilidade de evocar uma imagem forte em qualquer observador dado. É aquela forma, cor ou disposição que facilita a criação de imagens mentais claramente identificadas, poderosamente estruturadas e extremamente úteis do ambiente". (LYNCH, 2010, p. 11).

No caso da estátua d'O Laçador, o papel da escultura no local original consistia em um referencial profundamente identificado com a cidade e sua população. Como que recepcionando aqueles que a ela chegavam, ou mesmo despedindo-se daqueles que dela saíam.

Originalmente postado sobre pedestal elevado a cerca de dois metros do nível da rua, $O$ Laçador posicionava-se em eixo vertical em torno do qual circulavam automóveis distanciados de forma compatível com a visualização da escultura. Os veículos passantes se aproximavam em velocidades coerentes com o tráfego urbano (entre 40 e 60 km/h) e, em virtude de semáforos posicionados em torno da semirró- 
tula do Largo do Bombeiro, proporcionava instantes de observação mais demorada da escultura pelos seus ocupantes. A condição de visibilidade da obra estabelecia a sua presença no cotidiano urbano, oferecendo amplamente à apreciação dos que entravam e saiam da cidade naquele local. A escultura localizava-se "à moda clássica", em um ponto focal, exatamente na conversão que conduzia à entrada de Porto Alegre. Na discussão sobre o ponto focal e sua possível transmutação, Cullen (2009, p. 28) afirma que este:

[...] define a situação, surge como uma confirmação: 'É este o local que procuravam. Pare. É aqui.' Em muitas povoações possui ainda esta clareza deslumbrante, mas em muitas outras foi-lhe retirada essa função primordial pelas exigências do trânsito, que o isola, transformando-se, assim, num elemento indiferente, próprio dum 'carnet' de antiquário.

Na situação atual, mais elevado em relação ao solo, já que o pedestal de concreto está implantado no topo de um talude de 3,50 metros de altura e colocado em sítio paralelo à estrada de acesso à cidade, o monumento foi extraído de um contexto de maior vitalidade e circulação para um cenário de exposição aberto à visitação específica. A escala de tempo, balizada pela velocidade com que os carros circulam pela estrada, prejudicou sensivelmente a apreciação da escultura pelos passageiros, se comparada às condições originais de localização. $\bigcirc$ fator velocidade dificulta, ou mesmo impede, o contato visual necessário ao reconhecimento de um marco urbano. Do ponto de vista de quem realmente poderia ver o monumento, este se encontra atualmente fora do eixo viário, à margem do fluxo, e não mais participa das experiências de chegada e partida em relação a Porto Alegre.

Importa considerar que a legitimação de um monumento como marco identitário compreende muito mais do que a sua simples existência física como elemento urbano, abrangendo fatores objetivos e subjetivos que se entrelaçam em sua expressão e significância. As relações com o entorno urbano no qual está inserido, sua localização física, suas diferentes formas de abordagem pelas pessoas no conjunto monumento/ escala humana, a velocidade adequada para a contemplação do elemento urbano, são alguns, entre tantos fatores a considerar, em uma análise abrangente.

A mudança de local do Monumento d' $O$ Laçador implica também repensar sobre a sua radical transformação de uso, objetivo e subjetivo, que um marco de sua importância reflete na relação com os cidadãos. Após o deslocamento, $\mathrm{O}$ Laçador deixou de ser o monumento da recepção ou despedida para tornar-se mais um centro de visitação, com todas as decorrências que esse fato traz em seu escopo de significados. A relação da população com $O$ Laçador deixou, após a sua relocação, de constituir-se em ligação endógena para transformar-se em aproximação exógena.

A riqueza da trama de percepções e significados do monumento, envolvendo suas distintas relações com os habitantes e com os visitantes, perdeu-se no atual sítio. Identificamos o impacto causado pelo deslocamento na constituição da memória e da história da cidade. Augé (1998, p. 113) traz à tona essa perspectiva ao afirmar: 
Memoria e historia se conjugan en la ciudad. Cada uno de los habitantes de la ciudad tiene su propia relación con los monumentos que dan testimonio de una historia más profunda y colectiva. En este sentido, el recorrido urbano de cada individuo constituye una manera de apropiarse de la historia a través de la ciudad. Por supuesto no todos los que la recorren descifran esta referencia a la historia con exactitud, pero la referencia misma impregna todos los desplazamientos, especialmente cuando se cruzan los itinerarios de aquellos que viven en la ciudad y de aquellos que la visitan, y los turistas de un día recuerdan a los moradores de la ciudad que su "marco de vida" puede ser para otros un objeto de curiosidad y de admiración.

Concordamos com Novais (2010) quando afirma que "[...] a escultura pública é a escultura criada para espaços abertos da cidade com base em necessidades concretas a partir das vozes dos cidadãos, da paisagem, do entorno, do marco histórico, do lugar, etc.".

O deslocamento d'O Laçador verificou-se no sentido inverso ao desejado pela vitalidade urbana, de forma contundente na nova relação da população porto-alegrense e de seus visitantes com o símbolo identitário do monumento. Essa visão é reforçada por Santos, ao sinalizar para a complementaridade socioespacial: "[...] a História não se escreve fora do espaço, e não há sociedade a-espacial. O espaço, ele mesmo, é social". (SANTOS, 1979, p. 9). Pode-se acrescentar que, enquanto construção social, o espaço comunica ideias e induz comportamentos. Também é possível aludir à visão de Freire (1996, p. 50), segundo a qual "[...] há uma pedagogicidade indiscutível na materialidade do espaço".

O largo espectro de interpretações das intervenções urbanas apresenta cada vez mais o entrelaçamento de objetividades e subjetividades, que impulsiona a compreensão das "cidades para pessoas". Observa-se, dessa forma, que a concepção de urbanismo e de suas transformações são inerentes à complexidade dos fatores que compõem a vida dos cidadãos no que tange à sua relação com o sistema de objetos que dá forma aos ambientes da cidade.

\section{CONSIDERAÇÕES FINAIS}

Toda a cidade que tem um rio é bela. Porto Alegre exagera, [...] Com toda essa lindeza, gosto de tomar nossa cidade como modelo e temática. Tenho desenhado como ela era, como ela é e como a desejo. [...] Quando aqui cheguei, nos tempos do bonde, do rolo compressor e das balas esportivas, Porto Alegre ainda mantinha, ao menos no centro, um certo ar tradicional que lembrava Buenos Aires. Com o tempo, foi se tornando interesseira, substituindo seus cafés de esquina pelas agências financeiras. Além da inocência, perdeu nos últimos anos muito de sua identidade original. (VERÍSSIMO; FONSECA, 1996, p. 7).

A despeito dos poucos argumentos que possam ser elencados em defesa da remoção de $O$ Laçador e das possíveis vantagens do projeto do Sítio do Laçador, como o favorecimento à visitação por turistas, parece relevante a reflexão sobre o tema e, de maneira 
mais ampla, a reflexão sobre a preservação dos marcos urbanos. Algo muito caro aos porto-alegrenses perdeu-se na transferência d'O Laçador. Como já mencionado, para os residentes que chegavam ou partiam, passar pelo monumento era o momento de sentir-se em casa ou despedir-se. Ali se concretizava a chegada à cidade ou a partida da mesma, pelo contato com a figura forte e expressiva do gaúcho de Caringi. Para os visitantes, era um sinal de boas-vindas, o momento de reconhecimento de um cartão-postal, uma afirmação do significado de estar na capital gaúcha. Essa identidade, reforçada pela proximidade do aeroporto Salgado Filho, é ilustrada na figura 14.

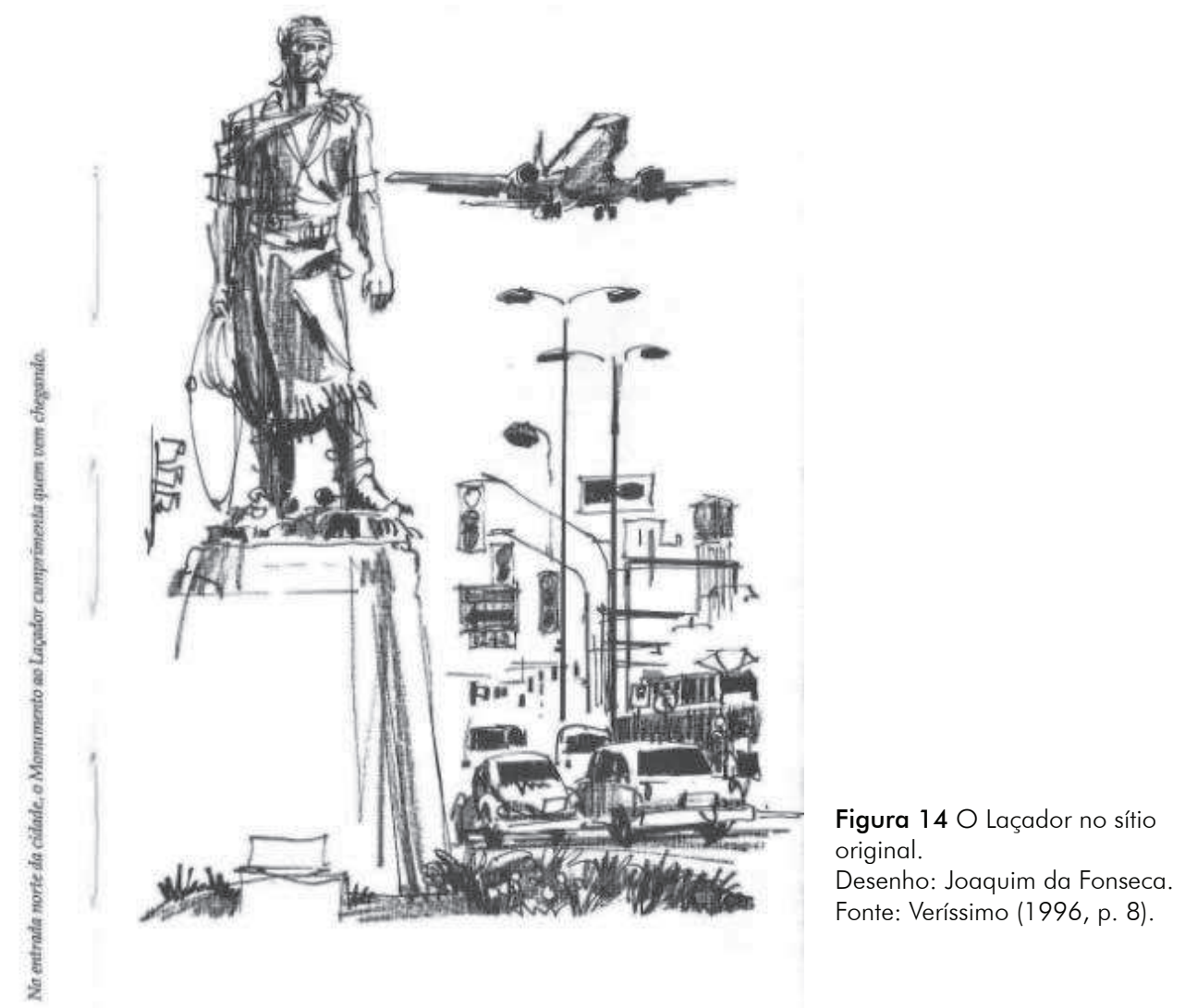

É preciso ressaltar que o presente artigo não tem o objetivo de emitir um juízo de valor, de forma maniqueísta, sobre o deslocamento do Monumento d'O Laçador. A intenção que aqui se apresenta é de aprofundar a reflexão sobre a significação e identidade conferidas aos monumentos públicos em sua inserção na cidade, que, para além de fatores meramente físico-geográficos, comporta observar a complexidade inerente a todo o estudo que pretende analisar com maior integralidade as nuances da vida cidadã.

No entanto, não poderíamos deixar de exercitar a posição política, no seu amplo sentido de tomar partido, em relação à questão aqui proposta. $\bigcirc$ deslocamento do Monumento d'O Laçador foi um erro. Alternativas como o desvio no eixo viário seriam perfeitamente factíveis e preservariam o conjunto cruzamento/elemento marcante citado por Lynch (1980) no corpo deste artigo. Esse fato é corroborado explicitamente 
nos depoimentos ${ }^{10}$ colhidos de habitantes de Porto Alegre de diversas faixas etárias e diferentes níveis sociais.

Ainda como justificativa para esta posição, verifica-se na atitude de estranhamento um sinalizador para a necessidade de resistência à transformação das cidades em mercadorias. $O$ deslocamento d'O Monumento do Laçador é apenas um dos exemplos no sentido de espetacularizar o cotidiano sob a forma de um local de visitação, trazendo com isso a descaracterização de sua profunda e genuína ligação com a cidadania. Pallasmaa (2013, p. 21) diferencia as imagens entre as que comandam e as que emancipam: "[...] as imagens focam e controlam a atenção e a consciência do sujeito com o objetivo de manipular emoções e comportamentos - ou liberam e inspiram sua imaginação ao abrir uma dimensão de liberdade imaginativa individual".

Atualmente, no sítio no qual foi confinado, O Laçador encontra-se "invisível", como que apartado da população que o consagrou como símbolo identitário. Provavelmente, o seu olhar no infinito, como tão bem definiu Paixão Côrtes, ressente-se de sua missão. Atualmente, o Monumento, como símbolo identitário de uma população e sua cultura, decididamente, não é mais: $O$ Laçador.

\section{REFERÊNCIAS BIBLIOGRÁFICAS}

ALVES, José Francisco. A escultura pública de Porto Alegre: história, contexto e significado. Porto Alegre: Artfolio, 2004. 262 p. il.

AUGÉ, Marc. Não lugares: introdução a uma antropologia da supermodernidade. Porto Alegre: Papirus, 1994. $110 \mathrm{p}$.

El viaje imposible: el turismo y sus imágenes. Barcelona: Gedisa, 1998. 143 p.

AXT, Gunter; SCLIAR, Moacyr. Parque Farroupilha - Redenção: histórias de Porto Alegre. Porto Alegre: Paiol, 2011.152 p. il.

CULLEN, Gordon. Paisagem urbana. Lisboa: Edições 70, 2009. 202 p. il.

DIAS, Elisa dos Santos. Entre chafarizes e cuias: representações e imposições da arte pública em Porto Alegre/ RS. 2012. 56 f. Trabalho de Conclusão de Curso (Bacharelado em Museologia) - Faculdade de Biblioteconomia da Universidade Federal do Rio Grande do Sul, Porto Alegre, 2012.

FLORES, Ana Berenice Hubner. Design, território e tecnologia 3D na preservação cultural em suporte material sustentável: estudo de caso do Monumento "O Laçador". 2012. 177 f. Dissertação (Mestrado em Design) - Escola de Engenharia e Faculdade de Arquitetura da Universidade Federal do Rio Grande do Sul, Porto Alegre, 2012.

FREIRE, Paulo. Pedagogia da autonomia. São Paulo: Paz e Terra, 1996. 165 p.

FUNDACIÓN Mon ROU. Gauchos. Monedas de la República Oriental del Uruguay. 1992. Disponível em: <http://www.monedasuruguay.com/ser/4-gaucho/1992.htm>. Acesso em: 26 de julho de 2015.

GUEDES, Berenice Lagos. O mito do gaúcho e suas repercussões na história da educação no Rio Grande do Sul. Revista Tempos e Espaços em Educação, v. 2, jan./jun. 2009, p. 53-68.

LYNCH, Kevin. A imagem da cidade. São Paulo: WMF Martins Fontes, 2010. 227 p. il.

10 Foram colhidos depoimentos de uma amostra significativa (trinta pessoas) sobre a concordância ou não da remoção da escultura. Entre eles destacamos um que ilustra a posição, de certa forma hegemônica, do grupo consultado: uma estudante questionada sobre a remoção respondeu: "Ah $\mathrm{O}$ Laçador... Somos do interior e quando vínhamos a Porto Alegre era uma festa no automóvel da família ao enxergá-lo. Por sinal, onde está esse Monumento?" 
MAGS, André. Polêmica em bronze: Paixão Côrtes aponta problemas no monumento $\bigcirc$ Laçador. Folclorista que serviu de modelo à estátua critica condições do local e o laço da escultura. Zero Hora, Porto Alegre, 11 nov. 2012. Notícias. Disponível em: <http://zh.clicrbs.com.br/rs/noticias/noticia/2012/1 1/paixao-cortes-aponta-problemasno-monumento-o-lacador-3948017.html>. Acesso em: 26 jun. 2015.

MÜTZENBERG, Lenice Lucia. A escultura pública de Antônio Caringi em Pelotas. 2006. 65 f. Monografia (Especialização em Patrimônio Cultural: Conservação de Artefatos) - Instituto de Artes e Design da Universidade Federal de Pelotas, Pelotas, 2006.

NOVAIS, Nanci Santos. Escultura e cidade: uma relação ampliada no âmbito da contemporaneidade. Cultura Visual, n. 14, dezembro/2010, Salvador: EDUFBA, p.41-52.

PAIXÃO, Antonina Zulema. A escultura de Antônio Caringi: conhecimento, técnica e arte. Pelotas: UFPel, 1988. 114 p. il.

PALLASMAA, Juhani. A imagem corporificada: imaginação e imaginário na arquitetura. Porto Alegre: Bookman, 2013. 152 p. il.

PORTO ALEGRE. Lei Complementar n 275/92, de 06 de abril de 1992. Dispõe sobre a proteção do Patrimônio Histórico, Cultural e Natural do Município de Porto Alegre, disciplina a integração de bens móveis e imóveis, cria incentivos ao tombamento e dá outras providências. Disponível em:

<http://www2.portoalegre.rs.gov.br/smc/default.php? reg=7\&p_secao=87>. Acesso em: 26 jun. 2015.

. Sítio do Laçador será inaugurado amanhã. Diário Oficial de Porto Alegre, ano XII, edição 2995. Porto Alegre, sexta-feira, 30 de março de 2007. Disponível em:

<http://lproweb.procempa.com.br/pmpa/prefpoa/dopa/usu doc/30marco07.pdf>. Acesso em: 26 jun. 2015. RIO GRANDE DO SUL. Projeto de Lei n 13/2006. Declara a "Estátua do Laçador" integrante do patrimônio histórico e cultural e escultura-símbolo do Estado do Rio Grande do Sul. Diário Oficial da Assembleia Legislativa, n 9255, Ano LXV, 52 ${ }^{a}$ Legislatura, $2^{a}$ Sessão Legislativa, Caderno de Processo Legislativo. Porto Alegre, 15 mai. 2008.

SANTOS, Milton. Espaço e sociedade. Petrópolis: Vozes, 1979. 152 p.

A Natureza do espaço: técnica e tempo, razão e emoção, 4 ed. São Paulo: Edusp, 2006. 259 p.

VERÍSSIMO, Luís Fernando; FONSECA, Joaquim da. Traçando Porto Alegre. Porto Alegre: Artes e Ofícios, 6 ed., 1996. 143 p. il.

Nota do editor

Submissão: 30 jun. 2015

Aprovação: 9 set. 2015 